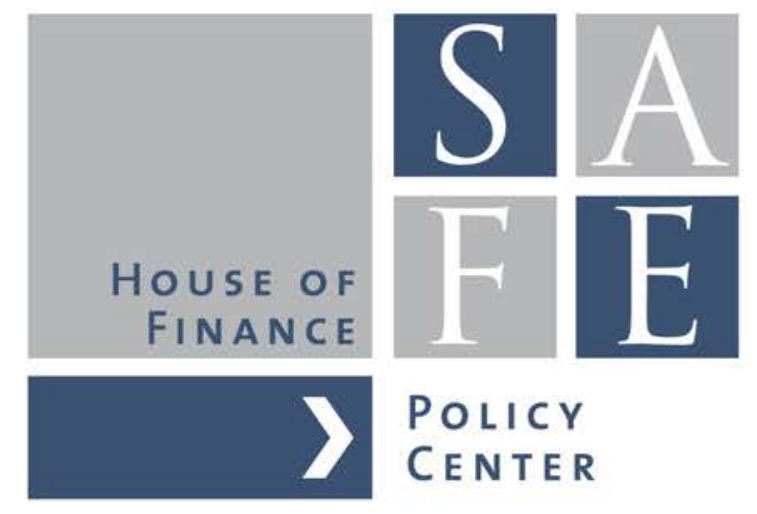

Thomas F. Huertas

\title{
Completing Banking Union
}

SAFE White Paper No. 63 | September 2019

SAFE I Sustainable Architecture for Finance in Europe A cooperation of the Center for Financial Studies and Goethe University Frankfurt 


\title{
Completing Banking Union*
}

\author{
Thomas F. Huertas \\ Goethe University Frankfurt, Center for Financial Studies, Institute for Law and Finance \\ and SAFE
}

September 2019

Abstract

To complete banking union, there should be a single European deposit insurance scheme (EDIS) alongside the single supervisor and the single resolution authority. This would ensure uniformity across the Eurozone and facilitate the removal of barriers to the mobility of liquidity and capital within the single market. That in turn would promote efficiency in the banking sector and in the economy at large - just at the time that the EU needs to boost growth in order to remain competitive with the US and China.

The EDIS promise to promptly reimburse insured deposits at a failed bank in the Eurozone should be unconditional. But who will stand behind that commitment? Who is the " $E$ " in EDIS? Is its promise credible, even in a crisis? If a deposit guarantee scheme fails to deliver what people expect, panic would very likely erupt. Instead of strengthening financial stability, deposit insurance could destroy it.

Yet this is the risk that current proposals pose. They create the impression that there will be a single deposit guarantee scheme. There will not. Instead, there will be a complex set of liquidity and reinsurance arrangements among Member State schemes.

These defects need to be remedied. To do so, we propose creating a European Deposit Insurance Corporation (EDIC) alongside national schemes. For banks that meet EDIC's strict entry criteria and decide to become members, EDIC will promise to reimburse promptly - in the event the member bank fails - 100 cents on the euro in euro for each euro of insured deposits, regardless of the Eurozone Member State in which the bank is headquartered.

In effect, the single deposit guarantee scheme would be created via migration to EDIC rather than mutualisation of existing schemes. This would increase the mobility of capital and liquidity and lead to

\footnotetext{
* SAFE policy papers represent the authors' personal opinions and do not necessarily reflect the views of the Research Center SAFE or its staff.

The paper will be published as a chapter in "EDIS, NPLs, Sovereign Debt and Safe Assets", Andreas Dombret and Patrick S. Kenadjian, editors, Institute for Law and Finance Series, De Gruyter 2019.
} 
a convergence of interest rates across the Eurozone. That in turn will improve the effectiveness of monetary policy, foster integration and promote growth.

\section{Introduction}

To complete banking union, there should be a single European deposit insurance scheme (EDIS) alongside the single supervisor and the single resolution authority. This would ensure uniformity across the Eurozone and facilitate the removal of barriers to the mobility of liquidity and capital within the single market. That in turn would promote efficiency in the banking sector and in the economy at large - just at the time that the EU needs to boost growth in order to remain competitive with the US and China.

If the "E" in EDIS is to be meaningful to the depositor EDIS is meant to protect, "E" can only mean one thing: that the holder of an insured deposit in a Eurozone bank will promptly receive 100 cents on the euro in euro, if the bank in which $\mathrm{s} /$ he holds the deposit fails. This promise should be unconditional. As far as insured deposits in the Eurozone are concerned, a euro should be a euro, regardless of the MemberState in which the deposit is placed, and regardless of how much money there may be in the deposit guarantee scheme.

In national schemes, such a promise effectively comes from the government. The government stands behind the guarantee given to insured deposits. That is appropriate, for the risk given resolution to insured deposits where insured deposits have preference comes predominantly from the possibility that the central bank and/or other authorities exercise forbearance and allow the bank to operate beyond the point of non-viability.

But who will stand behind the commitment that EDIS would make to depositors across the Eurozone? Who is the "E" in EDIS? Is its promise credible, even in a crisis? If a deposit guarantee scheme fails to deliver what people expect, panic would very likely erupt. Instead of strengthening financial stability, deposit insurance could destroy it.

Yet this is the risk that current proposals pose. They create the impression that there will be a single deposit guarantee scheme. There will not. Instead, there will be a complex set of liquidity and reinsurance arrangements among Member State schemes. Nor do the proposals designate the " $\mathrm{E}$ " that will backstop EDIS.

These defects need to be remedied. To do so, we propose creating a European Deposit Insurance Corporation (EDIC) alongside national schemes. For banks that meet EDIC's strict entry criteria and decide to become members, EDIC will promise to reimburse promptly - in the event the member bank fails -100 cents on the euro in euro for each euro of insured deposits, regardless of the Eurozone 
Member State in which the bank is headquartered. In effect, the single deposit guarantee scheme would be created via migration to EDIC rather than mutualisation of existing schemes. This would increase the mobility of capital and liquidity and lead to a convergence of interest rates across the Eurozone. That in turn will improve the effectiveness of monetary policy, foster integration and promote growth.

\section{Deposit insurance in a single national jurisdiction}

A deposit guarantee scheme ("DGS") protects insured deposits from loss in the event that a bank fails. ${ }^{1}$ If the resolution of the failed bank results in loss to deposits covered by the DGS, the DGS bears such loss, not the holder of the covered deposits. Moreover, deposit guarantee schemes undertake to reimburse covered deposits promptly, so that the depositors can continue to access such funds to meet their own obligations.

A DGS therefore curtails the contagion that could possibly arise, if unsophisticated depositors were to conclude from the failure of one bank that all banks were in trouble. With credible deposit insurance depositors have no incentive to withdraw deposits covered by the scheme. As far as the depositor is concerned, covered de posits are safe. The DGS bears any risk attributable to covered deposits and the DGS has the responsibility to monitor the bank holding such deposits.

Whether deposit insurance promotes or weakens financial stability depends on the design and execution of the guarantee scheme as well as on the interaction of deposit insurance with other aspects of bank regulation and supervision, including the access of troubled banks to lender of last resort facilities. ${ }^{2}$ On its own, deposit insurance creates moral hazard: if its deposits are insured, a bank may take more risk and therefore increase the probability that it will fail. ${ }^{3}$ To counteract this possibility, there should be restrictions on the ability of the bank to take risk, similar to the covenants that a private guarantor or creditor would impose. ${ }^{4}$

\footnotetext{
1 The core principles for effective deposit insurance schemes (IADI 2014) emphasize the importance of (a) making individuals and small-to-medium sized businesses eligible to receive deposit insurance, (b) ensuring $100 \%$ coverage of all deposits below a certain threshold (in the EU this is $€ 100,000$ ), (c) delivering on the commitment to reimburse covered deposits promptly, and (d) funding the DGS via premiums from banks, backstopped by a guarantee and/or line of credit from the government.

2 Demirgüç-Kunt and Detragiache (2002); Cerrone (2018).

${ }^{3}$ Anginer and Demirgüç-Kunt (2018)

${ }^{4}$ Dewatripont and Tirole (1994: xxx).
} 


\section{Graph 1}

\section{Super preference for insured deposits lowers risk to deposit guarantee scheme}

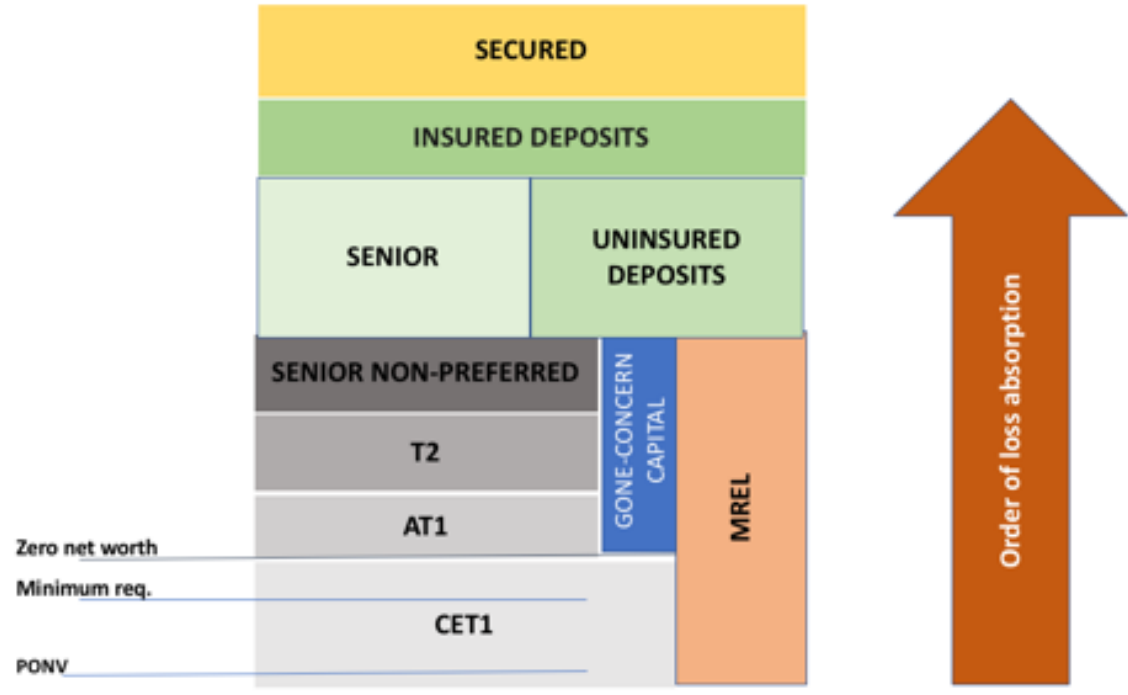

In banking, these restrictions take the form of regulation. The bank's license limits the activities in which the bank may engage. ${ }^{5}$ Various rules restrict the risk the bank may take in connection with permitted activities, whilst other requirements stipulate the capital and liquidity that the bank must maintain in order to conduct such permitted activities. Banks must regularly report their compliance with these restrictions and open themselves to official supervision. Finally, the resolution regime provides the remedies open to the deposit guarantor as well as to other creditors, if the bank does not meet regulatory requirements.

Thus, the risk to the DGS is a product of two factors: the probability that the bank will enter resolution, and the loss to DGS given that the bank has entered resolution. The latter depends critically on the point at which the authorities put the bank into resolution as well as on the amount of liabilities subordinated to covered deposits in the creditor hierarchy. The risk to the scheme is less, if the authorities put the bank into resolution no later than the point of non-viability (PONV). In such cases, the failed bank is likely to have positive net worth, so that there will be no loss attributable to covered deposits and accordingly no loss to the DGS. The risk to the scheme is also less, if insured deposits enjoy preference and there is a significant amount of uninsured liabilities (such as uninsured deposits) junior to covered deposits but senior to the instruments counting toward the bank's MREL requirement (see Figure 1). In such cases, losses would have to exceed not only the entire amount of

\footnotetext{
${ }^{5}$ Note, however, that such restrictions limit only the types of risk the bank may take, not the amount of risk the bank actually takes. For further discussion see Huertas 2016b.
} 
CET1 capital, but also all of the bank's gone-concerncapital (Additional Tier 1 and Tier 2 capital, senior non-preferred debt) as well as all of the bank's senior obligations and uninsured deposits before any losses would accrue to the bank's covered deposits. Thus, if authorities promptly put banks into resolution as soon as they reach the PONV, there should be little or no risk of loss to the DGS, and therefore only a limited burden for the DGS to bear.

\section{Graph 2}

Forbearance increases risk to deposit guarantee scheme Secured borrowing from central bank pushes insured deposits down the credit hierarchy
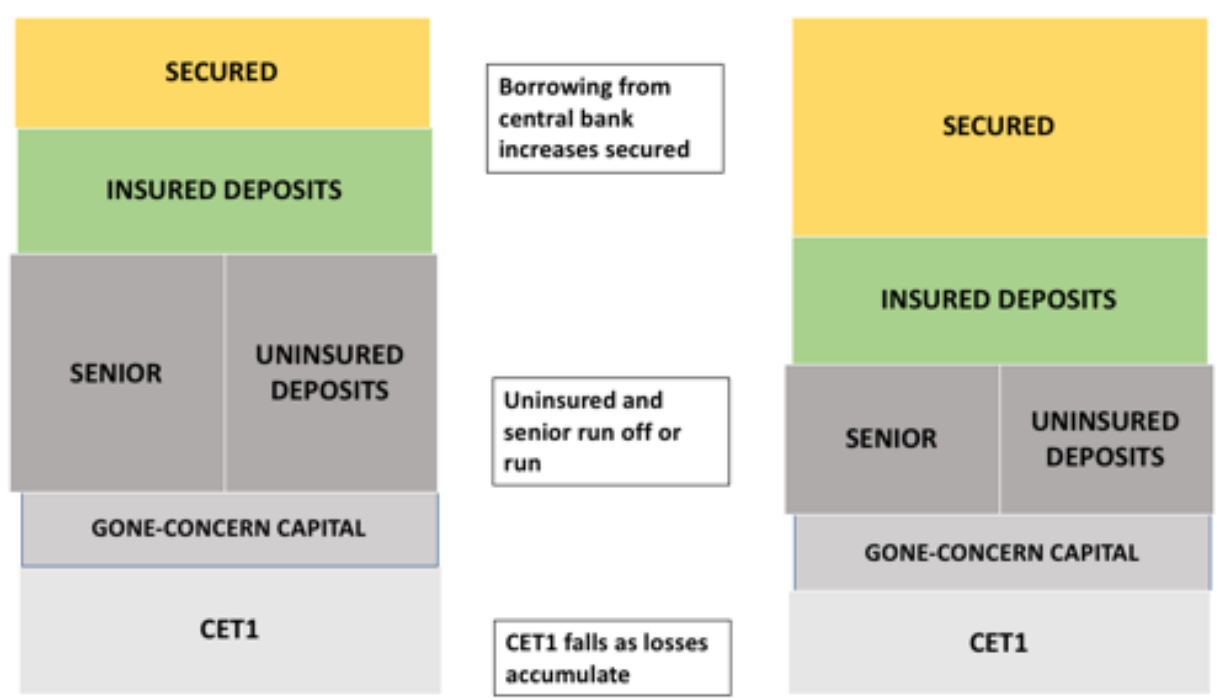

In contrast, the DGS may have a significant burden to bear, if the authorities exercise forbearance. In particular, emergency liquidity assistance (ELA) from the central bank may allow the bank to continue to operate beyond the PONV. If so, such secured lending raises the risk to the deposit guarantee scheme, for it pushes insured deposits down in the creditor hierarchy. Essentially, liabilities junior to insured deposits decline, and liabilities senior to insured deposits increase. This raises the likelihood that the DGS will incur a loss, if the authorities do eventually place the bank into resolution.

Accordingly, it is appropriate that the government backstop the commitment that the DGS makes to holders of insured deposits to reimburse covered deposits promptly, in the event that the bank holding the deposit fails. Indeed, it is this government backstop that makes the deposit guarantee scheme credible, that curtails contagion and promotes financial stability. ${ }^{6}$

\footnotetext{
${ }^{6}$ Bonfim and Santos 2017.
} 


\section{Deposit insurance in the Eurozone}

The Eurozone differs from other jurisdictions. The 19 Member States of the Eurozone are embedded in the EU (28 Member States [prospectively 27 after the exit of the UK]). The EU has established the European Banking Authority (EBA) as the single banking regulator in the $\mathrm{EU},{ }^{7}$ and the EBA has created a single rule book to which all credit institutions in the EU must adhere. ${ }^{8} \mathrm{Via}$ the Banking Recovery and Resolution Directive (BRRD) the EU has established the framework by which Member States must resolve credit institutions that are failing or likely to fail. ${ }^{9}$ And, via the Deposit Guarantee Schemes Directive (DGSD) the EU has established standards that each Member State's deposit guarantee schemes must meet. ${ }^{10}$

The MemberStates of the Eurozone have adopted the Euro as their common currency and delegated the management of that currency to the European Central Bank (ECB). ${ }^{11}$ In addition, the Eurozone Member States have created the Single Supervisory Mechanism (SSM) to conduct bank supervision within the Eurozone under the aegis of the ECB. The ECB directly supervises significant institutions in the Eurozone and sets the standards by which national competent authorities supervise the remaining institutions. ${ }^{12}$ Member States have also established the Single Resolution Mechanism (SRM) to implement the tasks assigned to the resolution authority under the BRRD under the direction of the Single Resolution Board (SRB). ${ }^{13}$

\footnotetext{
7 Under Regulation EU 2010/1093, the European Banking Authority (EBA) is the single regulator for credit institutions in the EU.

8 The European Banking Authority (EBA) has developed the Single Rulebook applicable to all credit institutions in the EU. It "provides a comprehensive compendium of the level 1 text for the Capital Requirements Regulation (CRR) and the Capital Requirements Directive (CRD); Bank Recovery and Resolution Directive (BRRD); the Deposit Guarantee Schemes Directive (DGSD); the Payment Services Directive (PSD); the Mortgage Credit Directive (MCD) and the corresponding technical standards developed by the European Banking Authority (EBA) and adopted by the European Commission (RTS and ITS), as well as the EBA Guidelines and related Q\&As." The interactive version may be accessed at www.eba.europa.eu.

9 EU 2014a and EU 2019a (BRRD II).

10 Under the Deposit Guarantee Schemes Directive (EU 2014c) the EU required Member States to have at least one deposit guarantee scheme and to ensure that each bank headquartered within its jurisdiction belonged to a deposit guarantee scheme. Such schemes must protect the deposits of individuals and SMEs up to a limit of $€ 100,000$ per depositor per bank and must reimburse promptly insured depositors at a failed bank. In addition, the DGSD harmonised funding according to the ex ante principle as well as set a minimum target funding ratio for deposit guarantee schemes in the EU (see Funding below).

11 ECB 2014b provides details of the legal framework under which the ECB and the Eurosystem of national central banks operate.

12 For Member States in the Eurozone the Single Supervisory Mechanism subjects the prudential supervisory activities of national competent authorities to the oversight and direction of the ECB, specifically to the Single Supervisory Board. For details of the Regulation see ECB 2014a.

13 For member states in the Eurozone the Single Resolution Mechanism establishes the Single Resolution Board as the resolution authority responsible for the resolution of credit institutions headquartered in such Member States. The SRB has the responsibilities and powers assigned to and required for a resolution authority under the terms of the BRRD. It delegates the implementation of its decisions to national resolution authorities. For details see EU 2014b and EU 2019b.
} 
However, emergencyliquidity assistance (ELA) and deposit insurance remain the responsibility of each Member State. National central banks can provide ELA to troubled banks, subject to no objection from the ECB. The ECB can only object to ELA on the grounds that ELA could compromise monetary policy. ${ }^{14}$ Currently, deposit insurance is the responsibility of each Member State, and its government effectively stands behind its deposit guarantee scheme(s). But this backstop has limits. A Member State cannot simply create euros. It has to collect them in taxes or borrow them in the market. Hence, bank failures may not only exhaust the capacity of the DGS, but also the capability of the government to support it. Such was the case in Cyprus. ${ }^{15}$ And, if the government itself had to reschedule its debts, the backstop could vanish, just at the time it might be most needed (since the debt rescheduling could push banks to or beyond the point of non-viability). Such was the case in Greece. ${ }^{16}$

In both cases, the Eurozone Member States collectively developed an ad hoc solution for insured deposits as part of the overall restructuring program for the country. Although insured deposits up to the coverage limit were protected from loss, depositors faced strict limits on the amounts that they could withdraw, especially in cash. That restricted their ability to transact and hindered economic recovery.

Would insured depositors in Cyprus and Greece have fared better, if EDIS had been in place? In the popular imagination, yes. They would have promptly received 100 cents on the euro in euro for each euro of their covered deposits with no restrictions on their ability to access such funds. In other words, as far as the insured deposits were concerned, EDIS would have operated much the way that the FDIC operates in the United States. ${ }^{17}$

\footnotetext{
${ }^{14}$ ECB 2017. The ECB may request confirmation from the national competent authority (NCA) that the troubled bank is still solvent. The national central bank also determines the collateral that the troubled bank must provide. 15 In 2012 banks in Cyprus failed as a result of losses incurred on their holdings of Greek government bonds as a result of the write-off and rescheduling of such debt held by private creditors ("private sector involvement"). The loss to insured deposits far exceeded the capacity of the Cypriot scheme to reimburse such deposits. In the overall restructuring program for the country, insurance coverage was ex post restricted to EU residents and access of such residents to their funds was restricted. For details see Michaelides and Orphanides (2016) and Theodore and Theodore (2016). For a general discussion of backstops and mutualisation within the EU see Nieto 2016.

16 Banks in Greece also suffered large losses as a consequence of "private sector involvement" and the subsequent recession. However, Greek banks generally continued in operation, thanks to liquidity from the ECB (via normal lending facilities under softer collateral requirements) and from the Bank of Greece (via ELA) pending recapitalisation of the banks in the context of the overall restructuring programme for Greece. For details, see Mourmouras (2017) and Götz et al. (2018).

17 The FDIC has an outstanding record of consistently and promptly reimbursing insured deposits of failed banks. In part this is due to its ability to prop up the failing bank until it has completed its preparations and is ready to push to push the failing bank over into resolution. As a result, depositors in the US have come to expect that their deposits covered by the FDIC will be immune from loss and practically exempt from suspension.
} 


\section{What stands in the way of EDIS?}

In theory, there should be little that stands in the way of EDIS. The single regulator's single rule book requires that banks keep capital in relation to the risks that banks run. The single supervisor determines (on the basis of the bank's individual capital adequacy assessment process [ICAAP], ${ }^{18}$ the supervisory review and evaluation process [SREP] ${ }^{19}$ and system-wide stress tests ${ }^{20}$ ) the amount of "going concem" capital (common equity tier 1 [CET1] capital) that the bank must maintain. This lowers the probability that the bank will fail and enter resolution.

Under the Single Resolution Mechanism the Single Resolution Board (SRB) mandates that significant institutions in the Eurozone create resolution plans and meet an institution-specific minimum requirement for own funds and eligible liabilities (MREL) so that they will have gone-concern capital sufficient to recapitalise the bank in the event that the bank fails. ${ }^{21}$ This "pre-pack" resolution process is meant to ensure that investors bear the cost of bank failures, and it creates the basis for the bankin-resolution to continue to perform its critical economic functions.

"Gone-concern" capital (additional Tier 1 capital, Tier 2 capital and qualifying senior non-preferred debt) ${ }^{22}$ lowers the likelihood that insured deposits will be subject to bail-in and the DGS exposed to loss. Under the BRRD this gone-concern capital is junior to other liabilities of the bank (see Figure 1 above). It can be bailed-in (written down or converted into CET1 capital) in the event the authorities determine that the bank is failing or likely to fail. ${ }^{23}$ If the authorities do in fact intervene in this prompt fashion, the bank is likely to still have positive net worth, and the bail-in of gone-concern capital is likely to recapitalise the failed bank.

\footnotetext{
18 In its ICAAP the bank must estimate the capital it will require to meet not only the risks it is currently running but also the risks it is likely to incur over the next twelve months, including risks for which regulatory capital is currently not required. For details see ECB 2018. The bank must also conduct a similar exercise for liquidity, the Individual Liquidity Adequacy Assessment Process (ILAAP). For details see ECB 2018c.

19 Under the SREP the ECB will determine for each significant institution in the Eurozone the Pillar 2 capital requirement for the bank according to guidelines established by the EBA (2018c).

20 In conjunction with the European Systemic Risk Board (ESRB) the EBA periodically conducts a system-wide stress test to determine the resiliency of the EU banking system to various shocks under scenarios developed by the ECB. For credit institutions in the Eurozone the ECB administers the test. For the methodology of the test see EBA 2018a and for the results see EBA 2018b.

21 The SRB determines the amount of MREL an institution should hold on the basis of a "default formula, made up of two components: (i) a default loss-absorbing amount (LAA), which reflects the losses that the bank will incur in resolution, and (ii) a recapitalisation amount (RCA), which reflects the capital needed to meet ongoing prudential requirements after resolution. The latter component is complemented by a market confidence charge (MCC), necessary to ensure market confidence post-resolution." (SRB 2018, p. 6).

22 For details see SRB (2018:10-14).

${ }^{23}$ The EBA has developed Regulatory Technical Standards for the key elements in the BRRD including the criteria for failure (EBA 2015) and bail-in (EBA 2017).
} 
Thus, if supervision and resolution work as outlined above, insured deposits are practically immune from loss. If authorities intervene promptly and the bail-in of "gone-concern" capital recapitalises the failed bank, the bank-in-resolution can resume operations the next business day with depositors retaining unrestricted access to their funds. In other words, under a pre-pack resolution insured deposits are not only immune from loss, but exempt from suspension. ${ }^{24}$

In effect, each bank has self-insured its covered de posits via the issue of gone-concern capital. Provided authorities do not exercise forbearance, the risk from the bank to the DGS should be zero. There is no burden for the DGS to bear, and consequently no burden to share.

However, theory alone cannot provide the basis for EDIS. Supervision and resolution do not yet work as outlined above. Forbearance persists. Sufficient MREL does not yet exist. Bank balance sheets contain current risks (e.g. non-performing loans) and prospective risks (e.g. sovereign exposures) against which they may maintain insufficient capital. Finally, EDIS lacks funding and EDIS lacks a credible backstop. Consequently, Eurozone Member States have, with varying degrees of enthusiasm, agreed that risk reduction should precede risk mutualisation. ${ }^{25}$

Forbearance persists. Since the crisis central banks have funded troubled banks. Thanks to "eligibility easing" by the ECB troubled Eurozone banks have been able to pledge worse and worse rated assets as collateral for normal lending facilities, including long-term lending facilities. ${ }^{26}$ In addition, national central banks have tended to transform emergency liquidity assistance into extended liquidity assistance. Indeed, in Greece, Cyprus, Ireland and Portugal ELA has remained outstanding for months, and in some cases years. ${ }^{27}$

As outlined above, such assistance may constitute forbearance. If so, claims on the DGS could be significant, as and when troubled banks are put into resolution - claims that many national deposit guarantee schemes are neither financially nor operationally able to bear (see funding below). ${ }^{28}$

\footnotetext{
${ }^{24}$ Huertas (2018). Note that resolution authorities may only use the bail-in tool, if it is in the public interest to do so. Unless the failing bank passes this test, it will be liquidated under the terms of the national insolvency procedures of the Member State in which the bank is headquartered. See Binder et al. (2019) for further details. ${ }^{25}$ For an economic analysis of this trade-off see Bénassy-Quéré et al. (2018).

26 Huertas (2017).

27 ECB (2017b), Mourmouras (2017), Praet (2016).

28 Deposit guarantee schemes are moving toward a uniform ex ante funding model (see EBA 2019) with a target fund level in 2024 equal to $0.8 \%$ of covered deposits. According to the DGSD (EU 2014) deposit guarantee schemes in the EU should be able to reimburse insured depositors within 7 days of the bank's failure. To do so the DGS must meet various operational challenges, including without limitation determining (a) to whom money should be paid; (b) the amount that each such person should receive; and (c) how and where such funds should be paid (for details see IADI 2012 and IADI 2014: 56). For a discussion of the operational challenges facing a DGS see Ognjenovic, 2017.
} 
Sufficient MREL does not yet exist. Banks have not yet met requirements for gone-concern capital. At the end of 2018 the principal components of gone-concern capital (AT1 and T2 capital) at significant institutions in the Eurozone amounted to only 3.6\% of risk-weighted assets, clearly an amount insufficient to recapitalise the bank, if it were to fail, much less to restore market confidence in the bank-in-resolution. It would also be an amount insufficient to allow the SRB to have recourse to the Single Resolution Fund. ${ }^{29}$ So banks may not yet have in place the gone-concern capital buffer that would protect operating liabilities in general and insured deposits in particular. This raises the risk to the DGS, for it increases the likelihood that bail-in could extend to insured deposits, if the bank were to fail.

It may take some time for banks to issue sufficient MREL. During 2019 the Single Resolution Board will finalise the requirements for gone-concern capital within the broader process of setting levels for minimum requirement for own funds and eligible liabilities (MREL) for each significant institution in the Eurozone. Banks will then have a period of time to issue the instruments necessary to meet these requirements.

Deposit guarantee schemes may already face significant claims. Supervisors have allowed (or, in the case of the SSB, been forced to allow) banks to continue to carry non-performing loans at historic cost even though the level of provisions for such loans is unlikely to cover fully the loss that the bank may incur on such loans over time. ${ }^{30}$ Thus, the economic value of the bank's capital may be substantially below its book value, perhaps even below minimum requirements.

Although the overall level of non-performing exposures (NPEs) has been declining in the Eurozone, NPEs remain a substantial problem at significant institutions (SIs) in several Member States. For example, at year end 2018 SIs headquartered in Italy stated a CET1 capital ratio of $12.7 \%$ and CET1 capital of $€ 124$ billion. However, Italian SIs had $€ 156$ billion in NPEs, $51.1 \%$ of which were covered by provisions. In absolute terms provisions against NPEs amounted to $€ 79$ billion, leaving $€ 77$ billion in NPEs net of provisions. This amounts to $62 \%$ of Italian SIs' outstanding CET1 capital. Consequently, if expected losses exceed the amount of provisions taken, the CET1 capital ratio at Italian SIs would fall from the stated level of $12.7 \%$ of RWAs to a lower level. Indeed, if all NPEs were to default and if the loss given default were $100 \%$, the CET1 capital would be reduced by $€ 77$ billion (the amount of unprovisioned NPEs) and the CET1 ratio at Italian SIs would fall to $4.8 \%$ (see Table 1). Alternatively (and

\footnotetext{
${ }^{29}$ The amount of AT1 and T2 capital is estimated as difference between total capital ratio and CET1 capital ratio in ECB (2019: 32). Under the BRRD the resolution authority may only have recourse to the Single Resolution Fund, if $8 \%$ of the liabilities of the bank have been bailed in.

30 The ECB (2018) modified its original guidelines on NPLS (ECB 2017a) in response to concerns expressed by the European Parliament.
} 
more plausibly), if the need for additional provisions is restricted to forborne exposures, the CET1 ratio would fall to $8.7 \%$ of RWAs, a level close to, if not already at the PONV. Similar issues arise in connection with SIs headquartered in Cyprus, Greece, Ireland, Portugal and Spain (see Table 1).

\section{Table 1}

\section{NPEs may pose risk to deposit guarantee schemes in the Eurozone Capital, non-performing and forborne exposures at significant institutions in the Eurozone, year-end 2018}

\begin{tabular}{|c|c|c|c|c|c|c|c|c|c|c|}
\hline & \multirow{2}{*}{\multicolumn{2}{|c|}{ CET1 capital }} & \multirow{2}{*}{\multicolumn{2}{|c|}{$\begin{array}{l}\text { Non-performing } \\
\text { Exposures }\end{array}$}} & \multicolumn{4}{|c|}{ Forborne exposures } & \multirow{2}{*}{\multicolumn{2}{|c|}{ Adjusted CET1 ratio }} \\
\hline & & & & & \multirow{2}{*}{\multicolumn{2}{|c|}{$\begin{array}{l}\text { Performing } \\
\text { Amount Coverage }\end{array}$}} & \multicolumn{2}{|c|}{ Non-performing } & & \\
\hline & \multirow{2}{*}{$\begin{array}{r}\text { Amount } \\
€ \text { bns }\end{array}$} & \multirow[b]{2}{*}{ Ratio } & \multicolumn{2}{|c|}{ Amount Coverage } & & & & Jverage & & \\
\hline & & & €bns & ratio & $€$ €bns & ratio & $€$ bns & ratio & NPEs & \\
\hline Belgium & 38.1 & $19.1 \%$ & 11.4 & $41.6 \%$ & 2.1 & $2.4 \%$ & 3.5 & $24.6 \%$ & $15.7 \%$ & $17.3 \%$ \\
\hline Germany & 185.7 & $15.4 \%$ & 40.1 & $40.8 \%$ & 10.0 & $3.8 \%$ & 21.3 & $42.4 \%$ & $13.4 \%$ & $14.0 \%$ \\
\hline Estonia & C & C & C & C & $c$ & C & C & C & C & C \\
\hline Ireland & 31.1 & $18.6 \%$ & 17.0 & $26.5 \%$ & 6.8 & $4.2 \%$ & 13.0 & $24.2 \%$ & $11.2 \%$ & $10.9 \%$ \\
\hline Greece & 26.0 & $15.3 \%$ & 88.3 & $48.1 \%$ & 16.0 & $7.9 \%$ & 35.3 & $38.3 \%$ & $-11.7 \%$ & $-1.5 \%$ \\
\hline Spain & 169.9 & $11.9 \%$ & 96.9 & $42.6 \%$ & 43.5 & $8.5 \%$ & .9 & $40.8 \%$ & $8.0 \%$ & $8.5 \%$ \\
\hline France & 347.9 & $14.2 \%$ & 138.8 & $48.0 \%$ & 14.1 & $7.1 \%$ & 31.2 & $41.6 \%$ & $11.3 \%$ & $13.2 \%$ \\
\hline Italy & 123.6 & $12.7 \%$ & 156.2 & $51.1 \%$ & 25.1 & $5.2 \%$ & 47.4 & $42.4 \%$ & $4.8 \%$ & $8.7 \%$ \\
\hline Cyprus & 3.1 & $13.9 \%$ & 10.0 & $46.7 \%$ & 1.7 & $3.0 \%$ & 4.9 & $36.8 \%$ & $-10.2 \%$ & $-3.6 \%$ \\
\hline Latvia & C & C & C & C & C & C & C & C & C & C \\
\hline Lithuania & 2.9 & $18.6 \%$ & 0.9 & $25.4 \%$ & 0.1 & $2.1 \%$ & 0.3 & $31.4 \%$ & $14.4 \%$ & $16.9 \%$ \\
\hline Luxembourg & 9.6 & $25.5 \%$ & 1. & $31.5 \%$ & 0.3 & $0.9 \%$ & 0.3 & $24.2 \%$ & $23.5 \%$ & $24.5 \%$ \\
\hline Malta & 1.5 & $15.5 \%$ & 0.5 & $27.7 \%$ & 0.1 & $3.9 \%$ & 0.3 & $28.8 \%$ & $11.5 \%$ & $13.0 \%$ \\
\hline Netherlands & 105.8 & $16.4 \%$ & 37.8 & $24.8 \%$ & 14.0 & $1.7 \%$ & 16.8 & $22.9 \%$ & $12.0 \%$ & $13.4 \%$ \\
\hline Austria & 35.0 & $13.6 \%$ & .8 & $51.6 \%$ & 2.5 & $3.8 \%$ & 4.4 & $47.2 \%$ & $11.4 \%$ & $12.3 \%$ \\
\hline Portugal & 15.3 & $12.7 \%$ & 20.2 & $51.4 \%$ & 4.0 & $2.0 \%$ & 9.4 & $55.2 \%$ & $4.6 \%$ & $7.7 \%$ \\
\hline Slovenia & 2.5 & $18.6 \%$ & 1.2 & $58.2 \%$ & 0.2 & $8.2 \%$ & 0.6 & $53.5 \%$ & $15.0 \%$ & $16.1 \%$ \\
\hline Slovakia & - & & - & - & - & - & - & - & - & - \\
\hline Finland & 35.9 & $17.1 \%$ & 8.5 & $25.8 \%$ & 3.6 & $0.9 \%$ & C & C & $14.1 \%$ & C \\
\hline Total & 1137.2 & $14.3 \%$ & 640.8 & $45.3 \%$ & 144.2 & $5.9 \%$ & 244.3 & $39.1 \%$ & $9.9 \%$ & $11.7 \%$ \\
\hline
\end{tabular}

Source: ECB (2019)

Deposit guarantee schemes face significant potential risk. Currently, banks may hold an unlimited amount of euro-denominated government bonds issued by Member States in the banking book at historic cost, free from capital requirements (as such bonds carry a zero risk weight). ${ }^{31}$ That reflects the view that such bonds are immune from reschedulingor default. They are not, as the case of Greece amply demonstrates. Indeed, if the sovereign reschedules or defaults on its debt fails, the banks that have invested heavily in its bonds may fail as well. ${ }^{32}$

\footnotetext{
${ }^{31}$ For an overview of the capital requirements applicable to exposures to sovereigns see BCBS 2017.

32 This confluence poses significant challenges for monetary policy. If the ECB decides to raise euro interest rates, this would increase the fiscal deficit in heavily indebted Member States and therefore tend to increase the risk premium that their governments would have to pay in order to raise funds. For both reasons the price of
} 


\section{Table 2}

\section{Applying Basel Accord treatment of sovereigns to Eurozone Member States would raise capital}

requirements

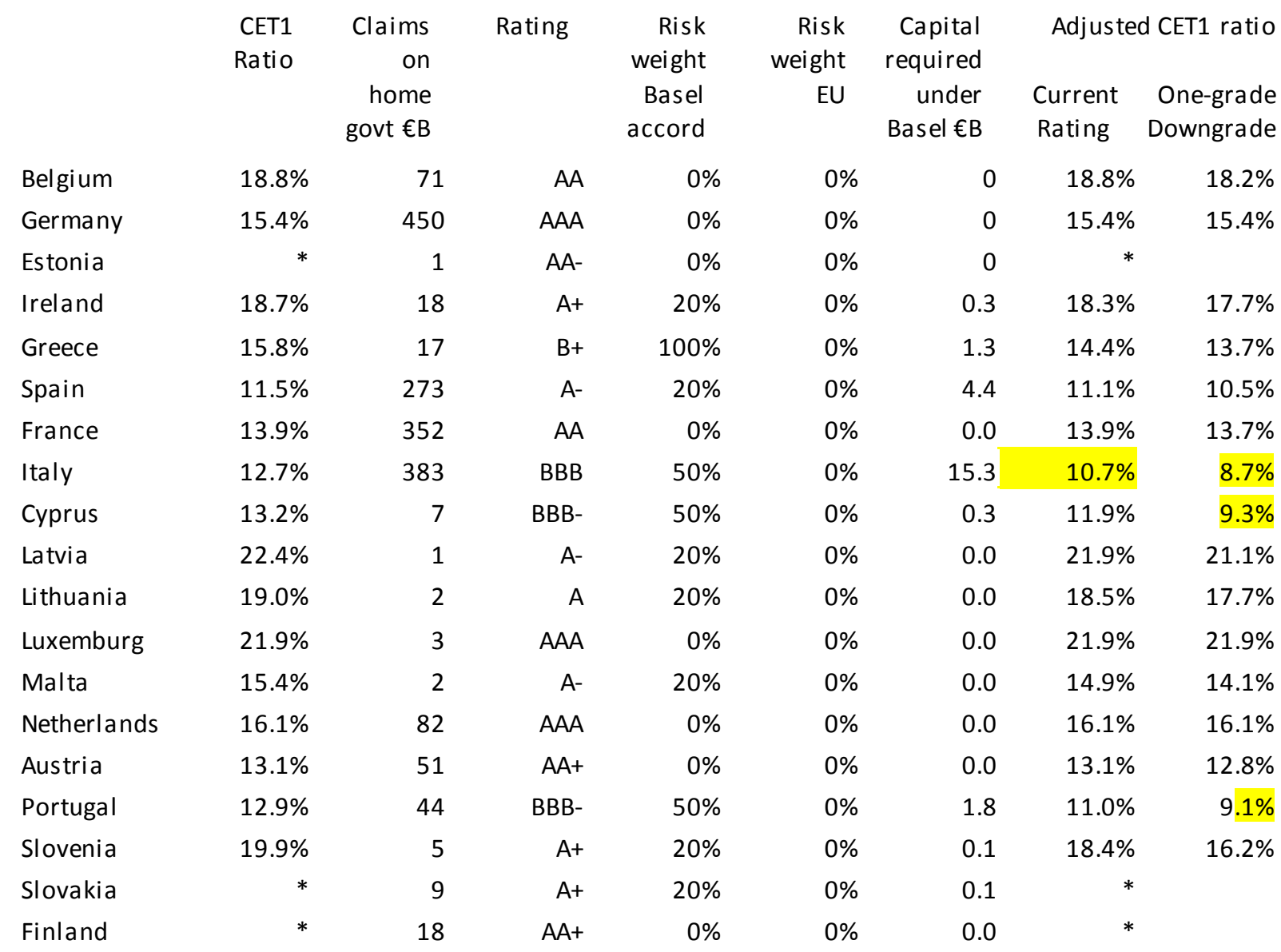

Source: Bruegel 2018, BCBS 2017.

Data on capital and exposures are for end June 2018. Ratings are end June 2019. An asterisk denotes that data is unavailable.

This risk is higher, the lower the credit rating of the sovereign in question. For sovereigns rated $A+$ or lower, the Basel accord requires banks to set aside capital to offset the risk that the sovereign could default. It assigns a risk weight of $20 \%$ to exposures rated " $A$ ", $50 \%$ to exposures rated BBB and $100 \%$ or more to exposures with a non-investment grade rating. Accordingly, the EU decision to accord all banking book exposures to Member States a zero risk weight allows banks to save significant amounts of capital. If EU banks had to keep capital with respect to sovereign exposures in line with the Basel standards, capital ratios at such banks would be up to two percentage points lower (this would be the case for Italian banks).

outstanding issues would fall, especially for long-dated fixed rate bonds. That would deplete the economic value of the bank's capital and push the banks holding such bonds toward default, especially in Member States where the market for such bonds is thin. The general rise in rates would also weaken further the position of creditors, making recovery of non-performing loans more difficult and in some cases impossible. 
Although this would in itself not be enough to push the banks to the point of non-viability, further downgrades in the credit rating of the sovereign might well do so, especially if that downgrade pushed the risk weighting over the cliff from single $A$ - to $B B B+$ or from $B B B-$ to $B B+.{ }^{33} A$ one full-grade downgrade in the sovereign's rating would be especially onerous for banks in Italy, Cyprus and Portugal (see Table 2).

Deposit guarantee schemes lack funding. Although deposit guarantee schemes in Eurozone Member States are rapidly accumulating the funds that they might require, in aggregate such funds only amount to $0.45 \%$ of covered deposits, barely more than half of the $0.8 \%$ target ratio established under the DGSD (see Table 3). Under the DGSD banks have until 2024 to reach the target ratio level.

\section{Table 3}

\begin{tabular}{|c|c|c|c|c|}
\hline \multicolumn{5}{|c|}{$\begin{array}{l}\text { Funding at deposit guarantee schemes in the Eurozone, } \\
\qquad \text { year-end } 2018\end{array}$} \\
\hline & $\begin{array}{r}\text { Covered deposits. } \underset{\text { billions }}{€} \\
\end{array}$ & $\begin{array}{r}\text { DGS fund. } € \\
\text { billions }\end{array}$ & $\begin{array}{r}\text { Coverage } \\
\text { ratio }\end{array}$ & $\begin{array}{r}\text { Shortfall to target. } \\
€ \text { billions }\end{array}$ \\
\hline Belgium & 292.8 & 3.70 & $1.25 \%$ & 0.0 \\
\hline Germany & 1815.3 & 8.20 & $0.45 \%$ & -6.3 \\
\hline Estonia & 9.4 & 0.20 & $2.37 \%$ & 0.0 \\
\hline Ireland & 106.1 & 0.30 & $0.30 \%$ & -0.5 \\
\hline Greece & 104.3 & 1.50 & $1.43 \%$ & 0.0 \\
\hline Spain & 726.3 & 2.00 & $0.28 \%$ & -3.8 \\
\hline France & 1168.1 & 4.10 & $0.35 \%$ & -5.2 \\
\hline Italy & 698.9 & 1.70 & $0.24 \%$ & -3.9 \\
\hline Cyprus & 9.4 & 0.02 & $0.24 \%$ & -0.1 \\
\hline La tvia & 8.5 & 0.20 & $2.14 \%$ & 0.0 \\
\hline Lithuania & 14.4 & 0.06 & $0.43 \%$ & -0.1 \\
\hline Luxembourg & 31.7 & 0.20 & $0.76 \%$ & -0.1 \\
\hline Malta & 12.0 & 0.10 & $0.97 \%$ & 0.0 \\
\hline Netherlands & 498.8 & 1.40 & $0.28 \%$ & -2.6 \\
\hline Austria & 218.7 & 0.60 & $0.30 \%$ & -1.1 \\
\hline Portugal & 144.0 & 1.80 & $1.25 \%$ & 0.0 \\
\hline Slova kia & 32.4 & 0.20 & $0.63 \%$ & -0.1 \\
\hline Slovenia & 18.9 & 0.05 & $0.28 \%$ & -0.1 \\
\hline Finland & 129.4 & 1.10 & $0.89 \%$ & 0.0 \\
\hline Total & 6039.4 & 27.43 & $0.45 \%$ & -23.9 \\
\hline
\end{tabular}

Source: EBA 2019b. In Member States with more than one DGS, the table represents the aggregate of such schemes.

\footnotetext{
33 Indeed, in such an environment banks with high exposures to low-rated sovereigns are more likely to fail, since
} such banks also have high levels of un-provisioned NPLs relative to CET1 capital (see above). 
The aggregate shortfall is nearly $€ 24$ billion. Larger Member States account for over $90 \%$ of this shortfall. The five largest Member States (Germany, France, Spain, Italy and the Netherlands) hold over $80 \%$ of covered deposits in the Eurozone: In these Member States the coverage ratio ranges from $0.24 \%$ (Italy) to $0.45 \%$ (Germany). In absolute terms Germany and France face the largest shortfalls. ${ }^{34}$

\section{Current proposals could be counterproductive}

In current proposals for EDIS the "E" is missing, both from the guarantee and the guarantor. EDIS would not guarantee to insured depositors across the Eurozone that they would promptly receive 100 cents on the euro in euro, if the bank holding that deposit failed. Nor would an "EDIC" be immediately created. Instead, the Commission is proposing that EDIS should essentially function as a reinsurance scheme for national plans. The Commission is proposing to introduce EDIS gradually, first restricting it to provision of liquidity to national schemes, then introducing EDIS as a co-insurer alongside national schemes before finally shifting to full mutualisation of risk under EDIS. ${ }^{35}$

This liquidity/reinsurance scheme carries three risks. First, it may weaken the protection that depositors currently have. De facto, insured depositors already have recourse to a European backstop. If a bank failure results in losses to insured deposits, the current chain of responsibility starts with the deposit guarantee scheme that covered the deposit, proceeds to the government of the Member State in which the scheme is located, and then to the European Stability Mechanism, either within the broader context of restructuring programs, or the narrower context of lending to support indirect or direct bank recapitalisation. Effectively, Commission proposals threaten to interject the deposit guarantee schemes of other Member States between the "exhausted" scheme and the government of the MemberState in which it is located, or between the scheme's Member State and other Member States (in other words, a Member State could have access to deposit guarantee schemes in other Member States without necessarily having to subject itself to the conditionality that would otherwise be imposed by the ESM). ${ }^{36}$

Second, current proposals increase the correlation risk facing banks in the Eurozone, and it is not inconceivable that supervisors will demand in the context of stress testing that banks hold higher capital against the possibility that they will be called upon to make higher contributions to their own

\footnotetext{
${ }^{34}$ For Member States with more than one scheme (e.g. Germany, Austria), the coverage ratios for the respective Member States in the text and in Table 3 represent the aggregate ratio for the country (sum of funds available to DG schemes/total covered deposits).

35 EC 2017 summarises the proposals and the positions of various stakeholders. Carmassi et al. (2018) provide an analysis. Howath and Quaglia (2017) detail political background.

${ }^{36}$ For details of the support that the ESM may currently provide to banks see ESM 2014.
} 
national DGS so that the DGS can meet demands for support coming from another Member State's scheme. ${ }^{37}$

The third and potentially most significant risk arises from a possible discrepancy between what the public believes EDIS to be and what EDIS actually delivers. Politically, EDIS is being sold as a guarantee that the insured depositor at a failed bank will promptly receive 100 cents on the euro in euro with no restrictions on access. In practice, s/he may not, and, if s/he does not, public confidence in deposit insurance could diminish, if not vanish entirely. This could cause a flight to quality (especially cash) and a run on banks perceived to be weak or headquartered in fiscally weak Member States. Instead of strengthening financial stability, EDIS as currently proposed could weaken it.

\section{The path(s) to EDIS}

Fortunately, perhaps, debate on EDIS has stalled. This creates space for alternative ways forward. One is to extend and expand risk reduction. Another is to create EDIC directly as a 28th regime alongside the 27 national schemes. ${ }^{38}$

\section{Continue to reduce risk}

This should not only encompass further efforts to reduce NPLs, but also include measures to reduce the risk posed by exposures to sovereigns as well as measures designed to reduce the likelihood of forbearance.

Reduce the risk posed by NPLs. This remains a high priority for the SSB, and it intends to use the supervisory methods at its disposal to induce banks to meet the standards set out in relevant regulatory guidelines. ${ }^{39}$ In addition, the introduction of the IFRS9 accounting standard will accelerate provisioning for non-performing exposures, at least for significant institutions (who are more likely to use IFRS). ${ }^{40}$

\footnotetext{
37 The risk posed by banks in Member State A to the deposit guarantee schemes (and therefore to the banks) in other Member States would be a product of three factors:

- $\quad$ the likelihood that banks in State A reach the PONV;

- the loss that the national deposit guarantee scheme would suffer, if such banks were put into resolution or liquidated; and

- $\quad$ the ability of the national DGS to bear such losses. This in turn will depend on the ability of the national scheme to retain its assessment base.

38 This numeration presumes that the UK will exit the EU. Restoy 2019 also proposes to create an EDIC, but this would result from the harmonisation of national schemes, rather than as a " $28^{\text {th" }}$ regime as proposed here. See also EP 2019.

39 Enria (2019).

40 Effective 2018 banks using the IFRS standard shifted to the expected loss method of provisioning (IFRS 9). Nonperforming loans are likely to be classified as category 2 so that banks will be required to take provisions for losses that may arise over the life of the loan. This will tend to increase provisions and reduce "hidden" losses. Although
} 
Reduce the risk posed by exposures to sovereigns. Although the creation of a risk-free asset may be desirable from the standpoint of monetary policy and capital market efficiency, ${ }^{41}$ it is not a necessary precondition for EDIS. Here the problem is that banks carry risks against which they do not hold capital. From an economic standpoint the solution is simple: require the banks to hold the appropriate amount of capital. However, from a political standpoint the solution is complex. It needs to avoid making explicit and apparent to all that Member States differ with respect to creditworthiness as well as avoid implying that governments of third countries, such as the United States, could ever default on their full faith and credit obligations. That rules out imposing capital requirements on exposures to sovereigns held in the banking book.

However, it does not rule out imposing capital on exposures to sovereigns in the trading book. Indeed, such exposures are already subject to capital requirements. ${ }^{42}$ Thus, one could reduce the risk from exposures to sovereigns by requiring that all such exposures be held in the trading book. This would ensure that such exposures are marked to market (and therefore reduce the possibility that capital is overstated) as well as require capital against possible future losses without having to opine officially on the creditworthiness of any Member State.

Table 4

\begin{tabular}{|c|c|c|}
\hline \multicolumn{3}{|c|}{$\begin{array}{l}\text { Proposed transition schedule for shifting exposures to sovereigns to trading book } \\
\text { at significant institutions in the Eurozone }\end{array}$} \\
\hline Remaining maturity & $\begin{array}{l}\text { If included in HQLA } \\
\text { toward LCR requirement }\end{array}$ & $\begin{array}{l}\text { Other exposures } \\
\text { in banking book }\end{array}$ \\
\hline Greater than 10 years & 2019 & 2020 \\
\hline Greater than 5 years & 2020 & 2021 \\
\hline Greater than 2 years & 2021 & 2022 \\
\hline Greater than 1 year & 2022 & 2023 \\
\hline Greater than zero & 2023 & 2024 \\
\hline
\end{tabular}

To minimise the possible disruption that such a measure might unleash, it could be restricted, at least at first, to significant institutions within the Eurozone. For such institutions the SSM could introduce this requirement gradually, starting first with longer-dated bonds (see Table 4) and requiring from end

\footnotetext{
there is a transition period during which banks may defer taking such additional provisions into account for the purposes of calculating capital requirements, banks that do so must disclose any benefit that they realise. For details see EBA $2018 \mathrm{~d}$.

${ }^{41}$ On the desirability and practicality of developing a safe euro asset (as well as proposals for how to do so) see Bénassy-Quéré et al. (2018).

42 BCBS 2019
} 
2020 forward the disclosure of any capital benefit the bank may receive from continuing to hold exposures in the banking book. ${ }^{43}$

Limit forbearance. In addition to reducing NPLs and ensuring that banks hold capital against their exposures to sovereigns, Eurozone Member States should take steps to limit forbearance, at least for significant institutions.

Here two measures are advisable. The first is to shift responsibility for ELA for SIs from national central banks to the ECB. This puts the ELA decision in the same overall entity that has to determine whether an $\mathrm{SI}$ is failing or likely to fail. It also puts the LoLR decision at the same Eurozone level at which any EDIS is expected to operate. This removes any temptation that individual Member States could have to defer resolution/exercise forbearance in the expectation that the Member State could shift any additional cost that such a delay might cause to EDIS (and therefore to other Member States).

The second measure is to requireSIs in the Eurozone to keep currentthe valuations that the SRB would require to trigger bail-in. This facilitates the ability of the authorities to intervene promptlyand to put the bank into resolution as soon as it reaches the PONV. ${ }^{44}$

Go directly to EDIS: create EDIC

In addition to reducing risk, Eurozone Member States should consider establishing EDIS directly via the creation of a European Deposit Insurance Corporation (EDIC). This entity would promise to reimburse promptly holders of covered deposits at a failed member bank 100 cents on the euro in euro. EDIC would exercise for its member banks the functions assigned to national resolution authorities in the Eurozone under the BRRD, including the implementation of any resolution plan.

Membership in EDIC would be open to any bank incorporated in a Eurozone Member State that fulfils upon admission all capital requirements, including those pertaining to MREL. In addition, EDIC member banks would be required, both initially and on an ongoing basis, to

- $\quad$ provision for non-performing exposures in accordance with IFRS 9 and SSB policy;

- hold all government bonds and derivative exposures to sovereigns in the trading book;

- keep current the valuations that the SRB would require for bail-in; and

\footnotetext{
${ }^{43}$ Arguably, given the decline in government bond yields, such a shift to the trading book at this time (end August 2019) would potentially result in a capital gain for some or all of the bonds held in the banking book. Any such gain would add to the bank's regulatory capital.

${ }^{44}$ In particular, banks would need to keep current the valuation required to determine whether the bank is failing or likely to fail as well as the valuation(s) required to determine whether it would be in the public interest to employ the resolution tool (bail-in). For details see EBA (2019a). Such valuations could be incorporated into the annual SREP with a requirement that they be updated more frequently, the weaker the condition of the bank.
} 
- maintain accurate data regarding the holders of insured deposits and the amount due to each such depositor (single-customer view)..$^{45}$

For such bank members of EDIC, the ECB, not the national central bank, would be the lender of last resort prior to resolution. This would place the responsibility for both supervision and emergency liquidity assistance at the ECB and therefore reduce the like lihood of forbearance. The ECB would also provide liquidity facilities to an EDIC member bank, if it were to enter resolution, taking as collateral the unencumbered assets of the failed bank. This would facilitate the resolution of the failed bank via bail-in. However, the ECB would not be responsible for any losses that EDIC might incur in connection with the liquidation or resolution of the failed bank. If EDIC incurs losses in excess of the fund accrued from premiums, EDIC may draw on a backstop to be provided by the European Stability Mechanism (ESM), pending subsequent recovery of such losses from additional premiums on EDIC member banks. EDIC would charge its member banks a premium based on the risk to covered deposits at the member bank. This would be inversely scaled to the amount of gone-concern capital outstanding at the bank relative to its risk-weighted assets. For member banks that maintained gone-concern capital sufficient to recapitalise the bank, deposit insurance premiums would be minimal (e.g. 3 basis points per euro of covered deposits). They would be nominal in amount (e.g. 0.5 basis point per euro of covered deposits), if the bank's uninsured deposits and other unsecured operating liabilities were greater than the bank's MREL requirement. In other words, EDIC member banks would not be charged premiums against the possibility that the authorities may wish to exercise forbearance.

Banks that are members of EDIC would not be members of national schemes and would not be required to pay premiums to national schemes. Although this would potentially undermine the viability of national schemes, it would also accelerate the shift to EDIC, so that banking union is achieved, not through the federation of national regimes, but through the creation and growth of a single euro regime. ${ }^{46}$ Finally and perhaps most importantly, EDIC member banks would face no restrictions on the movement of capital and liquidity across the offices of the bank in the Eurozone. ${ }^{47}$

\footnotetext{
45 In addition, EDIC should give consideration to measures that would facilitate payout and/or insured deposit transfer. These could include the establishment of a special purpose bank to which the bank's insured deposits and an equivalent amount of good assets might be transferred immediately upon the determination that the bank is failing or likely to fail. In addition, consideration might be given to requiring member banks to organise themselves as an SE. This would make it easier for EDIC to transfer the headquarters of the bank in resolution from one Member State to another and so provide EDIC with additional flexibility.

46 The withdrawal of a credit institution from a national scheme will reduce the scheme's assessment base and therefore the ongoing premium income for the scheme, but it will raise the ratio of the deposit insurance fund to the (now lower) amount of covered deposits.

47 In particular, there would be no restrictions on EDIC member banks establishing branches in other Member States, or on using deposits in one Member State to fund assets originated in a branch in another Member State.
} 
Such a regime would have several favourable features. It ensures that an insured deposit in euros at a member bank is worth 100 cents on the euro in euros in the event the bank fails, regardless of the Eurozone Member State in which the bank is located. It would therefore remove the distinction between deposits in different Member States, at least for banks that are members of EDIC. EDIC would also weaken the doom loop. It would open the door to greater freedom of movement for capital and liquidity within the Eurozone. Together these effects would lead to a convergence of interest rates across the Eurozone. That in turn will improve the effectiveness of monetary policy, foster integration and promote growth.

\section{References}

Anginer, D. and A. Demirgüç-Kunt (2018) Bank Runs and Moral Hazard: A Review of Deposit Insurance, World Bank Working Paper No. 8589.

Bénassy-Quéré, A., M. Brunnermeier, H. Enderlein, E. Farhi, M. Fratzscher, C. Fuest, P. Gourinchas, P. Martin, J. Pisani-Ferry, H. Rey, I. Schnabel, N. Véron, B. Weder di Mauro and J. Zettelmeyer (2018) Reconciling Risk Sharing with Market Discipline: A Constructive Approach to Euro Area Reform, CEPR Policy Insight No. 91.

BCBS (2017) Basel Committee on Banking Supervision. The regulatory treatment of sovereign exposures, Discussion Paper No. 425.

BCBS (2019) Basel Committee on Banking Supervision. Minimum capital requirements formarket risk. Discussion Paper No. 457.

Binder, J.- H., M. Krimminger, M. J. Nieto and D. Singh (2019) The choice between judicial and administrative sanctioned procedures to manage liquidation of banks: A transatlantic perspective, Capital Markets Law Journal, 14(2), pp. 178-216.

Bonfim, D. and J. A. C. Santos (2017) The importance of deposit insurance credibility, AEA Meetings.

Bruegel 2018. Dataset on sovereign bond holdings. Available at: https://bruegel.org/wpcontent/uploads/2018/11/201810 Bruegel sovereign bond holding dataset.xlsx.

Carmassi, J., S. Dobkowitz, J. Evrard, L. Parisi, A. Silva and M. Wedow (2018) Completing the Banking Union with a European Deposit Insurance Scheme: who is afraid of cross-subsidisation?, European Central Bank Occasional Paper No. 208.

Cerrone, R. (2018) Deposit guarantee reform in Europe: does European deposit insurance scheme increase banking stability?, Journal of Economic Policy Reform, 21(3), pp. 224-239. 
Demirgüç-Kunt, A. and E. Detragiache (2002) Does deposit insurance increase banking system stability? An empirical investigation, Journal of Monetary Economics, 49(7), pp. 1373-1406.

Dewatripont, M. and J. Tirole (1994) The Prudential Regulation of Banks, Cambridge: M.I.T. Press.

EBA (2015) European Banking Authority. Guidelines on the interpretation of the different circumstances when an institution shall be considered as failing or likely to fail underArticle 32(6) of Directive 2014/59/EU, Final Report EBA/GL/2015/07.

EBA (2017) European Banking Authority. Final Guidelines concerning the interrelationship between the BRRD sequence of writedown and conversion and CRR/CRD, Final Guidelines EBA/GL/2017/02.

EBA (2018a) European Banking Authority. 2018 EU-Wide Stress Test, Methodological Note. Available at: https://eba.europa.eu/documents/10180/2106643/2018+EU-wide+stress+test+-

+ Methodological+Note.pdf.

EBA (2018b) European Banking Authority. 2018 EU-Wide Stress Test: Results, Report 2 November 2018. Availableat: https://eba.europa.eu/documents/10180/2419200/2018-EU-wide-stress-testResults.pdf.

EBA (2018c) European Banking Authority. Guidelines on common procedures and methodologies for the supervisory review and evaluation process (SREP) and supervisory stress testing, consolidated version, 19 July 2018, EBA/GL/2014/13.

EBA (2018d) European Banking Authority. Final report. Guidelines on uniform disclosures under Article 473a of Regulation (EU) No 575/2013 as regards the transitional period for mitigating the impact of the introduction of IFRS 9 on own funds, 12 January 2018, EBA/GL/2018/01.

EBA (2019a) European Banking Authority. Handbook on valuation for the purposes of resolution, 22 February 2019.

EBA (2019b) European Banking Authority. Deposit Guarantee Schemes data. Available at: https://eba.europa.eu/documents/10180/1904162/Aggregated+DGSD+data+-+2015-2016-20172018.xIsx/a185518b-1f6f-460b-ad11-ef08aca14b42

EC (2017) European Commission. Communication to the European Parliament, The Council, the European CentralBank, the European Economic and Social Committee and the Committee of the Regions on completing the Banking Union, COM(2017) 592 final, Brussels: 11 October 2017.

ECB (2014a) European Central Bank. Regulation (EU) No. 468/2014 of the European Central Bank of 16 April 2014 establishing the frameworkforcooperation within the Single Supervisory Mechanism between the European Central Bank and national competent authorities and with national designated authorities, SSMFramework Regulation, ECB/2014/17. Available at:

http://data.europa.eu/eli/reg/2014/468/oj.

ECB (2014b) European Central Bank. Legal Framework of the Eurosystem and the European System of CentralBanks, July 2014. 
ECB (2017a) European Central Bank. Banking Supervision. Guidance to banks on non-performing loans, March 2017. Available at:

www. bankingsupervision.europa.eu/ecb/pub/pdf/guidance on npl.en.pdf.

ECB (2017b) European Central Bank. Agreementon emergency liquidity assistance, 17 May 2017.

ECB (2018a) European Central Bank. Banking Supervision. Addendum to the ECB Guidance to banks on non-performing loans: supervisory expectations for prudential provisioning of non-performing exposures, March 2018.

ECB (2018b) European Central Bank. Banking Supervision. ECB Guide to the internal capital adequacy assessment process (ICAAP), November 2018.

ECB (2018c) European Central Bank. Banking Supervision. ECB Guide to the internal liquidity adequacy assessment process (ILAAP), November 2018.

ECB (2019) European Central Bank. Banking Supervision. Supervisory Banking Statistics, Fourth Quarter 2018, April 2019.

Enria, A. (2019) Non-performing loans in the euro area - where do we stand? Speech at the Conference "EDIS, NPLs, Sovereign Debt and Safe Assets" organised by the Institute for Law and Finance, Frankfurt, 14 June 2019.

EP (2019) European Parliament. Economic Governance Support Unit. Liquidation of Banks: Towards an 'FDIC' for the Banking Union?, Authors: J. Deslandes, C. Dias and M. Magnus.

ESM (2014) European Stability Mechanism. Guideline on Financial Assistance for the Direct Recapitalisation of Institutions, 8December 2014.

EU (2010) European Union. Regulation (EU) No. 1093/2010 of the European Parliament and of the Council of 24 November 2010 establishing a European Supervisory Authority (European Banking Authority), amending Decision No. 716/2009/EC and repealing Commission Decision 2009/78/EC. Available at http://data.europa.eu/eli/reg/2010/1093/oj.

EU (2014a) European Union. Directive 2014/59/EU of the European Parliament and of the Council of 15 May 2014 establishing a framework for the recovery and resolution of credit institutions and investment firms and amending Council Directive 82/891/EEC, and Directives 2001/24/EC, 2002/47/EC, 2004/25/EC, 2005/56/EC, 2007/36/EC, 2011/35/EU, 2012/30/EU and 2013/36/EU, and Regulations (EU) No 1093/2010 and (EU) No 648/2012, of the European Parliament and of the Council.

EU (2014b) European Union. Regulation (EU) No. 806/2014 of the European Parliament and of the Council of 15 July 2014 establishing uniform rules and a uniform procedure for the resolution of credit institutions and certain investment firms in the framework of a Single Resolution Mechanism and a Single Resolution Fund and amending Regulation (EU) No 1093/2010. Available at:

http://data.europa.eu/eli/reg/2014/806/oj.

EU (2014c) European Union. Directive 2014/49/EU of the European Parliament and of the Council of 16 April 2014 on deposit guarantee schemes (recast). 
EU (2019a) European Union. Directive (EU) 2019/879 of the European Parliament and of the Council amending Directive 2014/59/EU as regards the loss-absorbing and recapitalisation capacity of credit institutions and investment firms and Directive 98/26/EC.

EU (2019b) European Union. Regulation (EU) 2019/877 of the European Parliament and of the Council of 20 May 2019 amending Regulation (EU) No. 806/2014 as regards the loss-absorbing and recapitalisation capacity of credit institutions and investment firms. Available at:

http://data.europa.eu/eli/reg/2019/877/oj.

Götz, M.R., R. Haselmann, J. Krahnen and S. Steffen (2015) Did emergency liquidity assistance (ELA) of the ECB delay the bankruptcy of Greek banks?, SAFE Policy Letter No. 46, Goethe University Frankfurt am Main. Availableat: http://hdl.handle.net/10419/118645.

Howarth, D. and L. Quaglia (2017) The difficult construction of a European Deposit Insurance Scheme: a step too far in Banking Union?, Journal of Economic Policy Reform, 21(3), pp. 190-209.

Huertas, T.F. (2016a) European Bank Resolution: Making it Work! CEPS Task Force Report, 26 January 2016. Availableat SSRN: $\underline{\text { https://ssrn.com/abstract }=2723220 .}$

Huertas, T.F. (2016b) Six structures in search of stability, in Patricia Jackson (ed.) Banking Reform, SUERF Conference Proceedings 2016/2, pp. 73-88. Availableat:

http://papers.ssrn.com/sol3/papers.cfm?abstract id=2662251.

Huertas, T.F. (2017) Eligibility easing and the lender of last resort, Vox CEPR Policy Portal, 21 April 2017.

Huertas, T.F. (2018) Calibrating Capital: When Will Banks Have Enough?31 January 2018. Available at: http://dx.doi.org/10.2139/ssrn.3036925

IADI (2012) International Association of Deposit Insurers. Enhanced Guidance for Effective Deposit Insurance Systems: Reimbursement Systems and Processes, Guidance Paper, November 2012.

Available at: https://www.iadi.org/en/assets/File/Papers/Approved\%20Guidance\%20Papers/IADI-

Reimbursement Enhanced Guidance Paper.pdf.

IADI (2014) International Association of Deposit Insurers. IADI Core Principles for Effective Deposit Insurance Systems, November 2014. Available at:

https://www.iadi.org/en/assets/File/Core\%20Principles/cprevised2014nov.pdf.

Michaelides, A. and A. Orphanides (2016) The Cyprus Bail-in: Policy Lessonsfrom the Cyprus Economic Crisis, London: World Scientific.

Mourmouras, I. (2017) On Emergency Liquidity Assistance: theory and evidence, Speech delivered at Oxford University's “The Political Economy of Financial Markets" (PEFM) programme, 27 February 2017.

Nieto, M. J. (2016) Bank Resolution and Mutualization in the Euro Area. European Economy, Banks, Regulation, and the Real Sector 2016-2. Available at SSRN: https://ssrn.com/abstract=3057503. 
Ognjenovic, D. (2017) Deposit Insurance Schemes: Funding, Policy and Operational Challenges, London: Palgrave Macmillan.

Praet, P. (2016) The European Central Bank and its role as lender of last resort during the crisis, Speech at "The Lender of Last Resort: An International Perspective", a conference sponsored by the Committee on Capital Markets Regulation, Washington DC, 10 February 2016.

Restoy, F. (2019) How to improve crisis management in the banking union: a European FDIC?, Speech before Centro de Investigação sobre Regulação e Supervisão Financeira at the Annual International Conference on "Financial supervision and financial stability 10 years after the crisis: achievements and next steps", Lisbon (Portugal), 4 July 2019. Available at:

http://www.bis.org./speeches/sp190715.pdf.

SRB (2018) Single Resolution Board. Minimum Requirement for Own Funds and Eligible Liabilities (MREL): 2018 SRB Policy for the first wave of resolution plans, 20 November 2018. Availableat: https://srb.europa.eu/sites/srbsite/files/srb2018mrelpolicy-firstwaveofresolutionplans.pdf.

Theodore, J. and J. Theodore (2016) Cyprus and the financial crisis: the controversial bailout and what it meansfor the Eurozone, London: Palgrave Macmillan. 